\title{
The toponymy of the villages in Ambon Island: A historical and archaeological study
}

\section{Toponimi desa-desa di Nusa Ambon: Kajian sejarah dan arkeologi}

\author{
Daya Negri Wijaya1,2*, Deny Yudo Wahyudi², Siti Zainatul Umaroh ${ }^{3}$, Ninie Susanti ${ }^{4}$, and \\ Rendy Aditya Putra Ertrisia ${ }^{5}$ \\ Universidade do Porto ${ }^{1}$, Department of History, Universitas Negeri Malang2, Center for Strategic and \\ International Studies Indonesia ${ }^{3}$, Department of Archaeology, Universitas Indonesia ${ }^{4}$ \\ Directorate of Cultural Protection ${ }^{5}$ \\ *daya.negri.fis@um.ac.id
}

\section{ABSTRAK}

Kata Kunci: Toponimi; Identitas budaya;

Leihitu;

Leitimor; etimologi

Keywords:

Toponymy; cultural

identity;

Leihitu;

Leitimor;

etymology

Article Submitted

Article Accepted

Artikel Published
Kajian toponimi baik di Kota maupun Nusa (Pulau) Ambon telah banyak dilakukan. Namun, kajian terdahulu belum menggunakan pendekatan sejarah dan arkeologi. Pendekatan sejarah dan arkeologi akan memudahkan peneliti untuk menyibak persilangan budaya. Pulau Ambon dipilih sebagai lokus kajian asal-usul nama desa dan persilangan budaya antara Jazirah Leihitu dan Leitimor. Terdapat tiga langkah yang ditempuh untuk mengambil dan menganalisis data dengan pendekatan sejarah dan arkeologi. Pertama, identifikasi dan tabulasi nama-nama desa yang disebutkan dalam Hikayat Tanah Hitu dan tiga peta kuno. Kedua, identifikasi berbagai peninggalan arkeologis yang terletak di desa-desa tersebut. Terakhir, analisis asal usul nama desa dengan mencari arti kata, mencari lokasi terkini, dan menjabarkan peran kebudayaan sezaman (masa Islam dan kolonial) di masa silam. Terdapat 12 desa dengan 22 peninggalan arkeologis yang ditemukan. Semua desa memiliki tinggalan budaya yang dapat menjelaskan dinamika masyarakat lokal setempat, namun hanya 10 desa yang dapat ditemukan arti dari nama desanya.

\section{ABSTRACT}

Previously, several toponymy studies have already been conducted both in the Nusa (Island) Ambon as well as in the City of Ambon. However, previous studies have not used the historical and archaeological approach. The use of this approach could ease the researchers to reveal the cross-cultural meeting in a specific locus. Taking the Island of Ambon as a locus, the researchers aim to find the origin of village names and the cultural intersection in Leihitu and Leitimor Peninsula. There were three steps conducted to collect and analyse data using historical and archaeological approach. Firstly, the researchers identified and took a tabulation of the village names, mentioned by the Hikayat Tanah Hitu (The Epic of Hitu Land) and three ancient maps. Secondly, the researchers identified various archaeological remains located in the scattered villages. Finally, the researchers analysed the origin of village names by searching the word-meanings, finding the present locations, and describing the role of the contemporary cultures (Islamic and Colonial period) in the past. The researchers found 12 villages with 22 archaeological remains. All related communities have the archaeological remains which could explain the local dynamics, but there are merely ten villages which name meanings could be identified.

\begin{tabular}{|c|c|c|c|}
\hline $\begin{array}{l}\text { BE } \\
0\end{array}$ & H & $\begin{array}{l}\text { VOLUME } \\
\text { DOI } \\
\text { VERSION } \\
\text { WEBSITE }\end{array}$ & $\begin{array}{l}: 41 \text { No.1, Mei 2021, 89-108 } \\
: 10.30883 / \text { jba.v41i1.600 } \\
: \text { English (translated) } \\
: \text { berkalaarkeologi.kemdikbud.go.id }\end{array}$ \\
\hline ISSN: 0216-1419 & E-ISSN: 2548-7132 & (c) (1) (9) (2) & $\begin{array}{l}\text { This work is licensed under a Creative Commons Attribution-Non } \\
\text { Commercial-ShareAlike } 4.0 \text { International License }\end{array}$ \\
\hline
\end{tabular}




\section{INTRODUCTION}

The origin of the name Ambon, both as the name of the island and as the name of the city, has been widely discussed. Ambon Island is located in Maluku Province and has two main districts, namely Ambon City and Central Maluku District. Ambon City is located in Ambon Bay and Leitimor Peninsula, which means Central Maluku District is on the north coast of Ambon Island or Leihitu Peninsula. Ambon City has several sub-districts namely Nusaniwe, Sirimau, Baguala, Ambon Bay, and South Leitimur Districts. Leirissa, Ohorella and Latuconsina (Leirissa et al., 1999, p. 66) explain that the name Ambon was taken from a local term, namely "ombong" which means "dew". Pattikayhatu (Pattikayhatu, 2008, p. 3) suggests that Ambon comes from the word "yapono" which also means "dew". Local people feel that Ambon Island, which has a hilly area, is often covered with dew. Sure enough, Leirissa, Ohorella and Latuconsina (Leirissa et al., 1999, p. 66) explain that the weather in Ambon is often covered with fog, even at certain times the mountain peaks on Ambon Island are covered with thick dew.

A cultural researcher from the Maluku Culture and Tourism Service Office, Manuhutu, has also studied Ambon City toponymy comprehensively which includes the names of the earth's features and the origins of place names in Ambon City (Manuhutu, 2002). Unfortunately, Manuhutu's study stalled on administrative boundaries in Ambon City. The development of Ambon City cannot be separated from the history of Ambon Island itself. Ambon City was built by the Portuguese in 1576 after they were driven from Hitu (Leirissa et al., 2004 , p. 17). The existence of a multicultural society could be seen if the locus of study is not only in the Leitimor Peninsula but also in Leihitu. Therefore, the diversity of Ambonese culture would be revealed if we examine it in a wider scope. This study will attempt to investigate the toponymy of Ambon Island.

The name of a place is a product of human creativity, sense and intentions. Humans have a tendency to name everything. This naming aims to facilitate communication between humans as well as a reference by pointing to a certain geographical object. Toponyms can be used to study these names. Toponymy can be understood as a science that studies toponyms (place names) and geographic names (Rais et al., 2008, pp. 4-5). Place names are usually understood from the linguistic, historical, and anthropological aspects only (Deliani, 2016; Suratminto, 2016; Widyastuti, 2016). In fact, place names will be meaningful if they are placed within the cultural framework (Islamic, Portuguese, and Dutch culture) and the historical context (15th to 19th centuries) that shape it (Munandar, 2016, p. 2).

Toponymy studies can assist archaeologists in explaining the relationship between place names and archaeological findings at a location. Agus Aris Munandar (Munandar, 2016, pp. 2-3) provides guidance that archaeologists must suspect (1) the names of places that can be traced to be from ancient languages and (2) there are ancient sites or buildings in the area that still stand today. Munandar (2016) tries to understand toponymy from the perspective of historical and archeological. This point of view will certainly make it easier to explain the toponym formation of villages in Nusa Ambon based on historical and archaeological data. Still according to Munandar (Munandar, 2016, p. 5), historical and archaeological data as cultural knowledge can be found in descriptions of literary works, myths, legends, and local history. If toponymy studies cannot be carried out independently, historical and archaeological studies are absolutely necessary. This study is intended not only to examine the origins of village names but also to highlight cultural crossovers in Nusa Ambon. 


\section{METHODS}

This study can be categorized as an archaeological and historical study. The study of the toponymy of villages in Nusa Ambon was provided with historical sources (The Epic of Hitu Land and Ancient Maps dating from 1617, 1665, and 1753) and archeological data (the Mosque of Wapauwe, House of the Soya King, the Hitu King's Headstone, Portuguese and Dutch Fortresses, and the Church of Soya), so that the formation of village names in Nusa Ambon can be explained in more depth. The research steps are carried out as follows:

1. Identify the names of the villages recorded in the Epic of Hitu Land (covering the period 1450-1646) as well as three ancient maps (those with high resolution dated from 1617, 1665, and 1753). The results of the identification of the data will be integrated in tabular form.

2. Identify various archaeological remains (both Islamic and colonial cultural remains) located in these villages. Guided by various secondary sources, both books such as the work of Paramita Abdurachman and journal articles such as the work of Wuri Handoko so that the distribution of archaeological remains on Ambon Island can be easily presented (Abdurachman, 2008; Handoko, 2014).

3. Referring to the eight toponymy analysis models from Munandar (Munandar, 2016, pp. 5-6), including analysis of the origin of village names by looking for the word meaning, looking for its current location, and describing the role of contemporary culture in the past. Search for place names based on Munandar's classification (Munandar, 2016, p. 1), which are names of plants, names of animals, historical events, myths and legends, teachings of religious and iconographic concepts, titles of past figures, and geographical conditions. Furthermore, search for the current locations of the names of the regions in the four sources. The similarity of words both in the arrangement of letters and pronunciation despite composed of several different letters are also considered. The list of names that have similarities is compared with population data for the administrative area of Ambon City and parts of Central Maluku District published by the Directorate General of Citizenship and Civil Registry of the Ministry of Home Affairs (Direktorat Jendral Kependudukan dan Catatan Sipil Kementerian Dalam Negeri, 2017). It is important to know the continuity or change in the pronunciation of the place names. In addition, satellite imagery is used to determine the suitability of the location or coordinates in the three ancient maps with the location of the most recent village or country or sub-district on Ambon Island today.

\section{RESEARCH RESULTS}

The ancient map with the oldest year 1617 used in this study is entitled "Pemandangan Amboina dari Atas dengan Potret Frederik Houtman, Gubernur Amboina" (A View of Amboina from Above with Portraits of Frederik Houtman, Governor of Amboina). The map illustration was made using painting techniques, with sufficient detail in depicting the surrounding natural environment. Locations that indicate a place are shown by a depiction combination of rows of palm or coconut trees with rows of building walls. The illustration was probably intended to depict settlements. At the top of the row of palm or coconut trees and on the wall, there is a field that contains thin writing. The thin writing is thought to be the place name of the location. 
A particular area that is illustrated quite prominently is the image of a fort on the north or lower offshore or southern side of Ambon Island. The fort has a square floor equipped with four bulwarks (strongholds) in each corner as well as settlements on the east, south and west of the fort. The fort is located at the place where Fort Nieuw Victoria is now located. An interesting part of the map is the inclusion of a portrait of Frederik Houtman, as former Governor of the VOC in Ambon. An ancient map dated 1617 shows 22 place names.

The second map dated 1665 is entitled "Peta Amboina" (Map of Amboina) which was painted in 1665. Unlike the previous one, this map does not describe the environmental conditions of Ambon Island or the existence of other islands around it. The map only contains the names of locations on Ambon Island with various sizes. The name with the largest and thickest font size is the name of Ambon Island. The name of the district or area unit under "Ambon Island" is written in a half to one third size smaller, but still in bold alphabet to distinguish it from the smaller regional units under it. These district locations are provided with colored demarcation lines that indicate the boundaries between regions. The smallest unit representing place names on this map is in very small, bold, and italic writings. The place names in the smallest unit in several locations appear to be written very softly and almost overlap, making them very difficult to identify. An ancient map dating back to 1665 shows 122 place names.

The map with the most recent chronology used in this study is "Peta Khusus Pulau Amboina Tahun 1753" (1753 Special Map of Amboina Island). The two previous maps are depicted in full color, while on this map it is not. This map dated to 1753 is depicted in black and white. The "North" cardinal point of the map points to the upper-right corner of the image, so it seems that the picture of Ambon Island is slightly different. The only landscapes depicted are just a series of mountains or hills that are scattered almost all over the island. Like the ancient map dated 1665, this third map also applies a large and bold writing system to distinguish the unit area coverage of a location. An ancient map dated 1753 shows 92 place names.

Previously, it was explained that The Epic of Hitu Land was also used as a reference in identifying place names on Ambon Island. The Epic of Hitu Land was written by Imam Rijali at the request of Karaeng Patingaloang in Makassar. This record was made by Imam Rijali in mid-1646 to 1657 when he managed to flee from Hitu to Makassar. The Epic of Hitu Land begins with a description of the arrival of four groups from North Seram, Java, Jailolo, and the Goron Islands who made settlements on the coast of North Ambon from 1450 to 1490 (Manusama, 1977, p. 1). Based on the identification of The Epic of Hitu Land, data on several location names were obtained. The names of places on Ambon Island that can be identified from The Epic of Hitu Land totaled 63 names. Although they cover a fairly long period of time, the names of places in The Epic of Hitu Land remain unchanged, for example the mention of Lisabata, Larike, Wai, and Loyi. However, it should be noted that The Epic of Hitu Land does not only mention the names of places in Hitu Peninsula, but also several names in other areas such as Leitimor Peninsula, Jailolo (Halmahera), Ternate, Banda, Gresik, Jepara, Makassar, to Feranggi (Portuguese). The accuracy of tracking the names of places mentioned in The Epic of Hitu Land can be ascertained. This is because it has been transliterated and published in the form of alphabetic text which and in Malay language which is easy to understand. 
The reading of the relatively small writings of the place names in the ancient maps dated 1617, 1665, and 1753 was done in consideration to the rules of appropriateness of letter arrangement and pronunciation. Based on the data above, the number of place names mentioned in The Epic of Hitu Land and Ancient Maps dating from 1617, 1665, and 1753 totaled 298. The process of reading names on ancient maps was carried out while matching them with the official names issued by the Directorate General of Citizenship and Civil Registry of the Ministry of Home Affairs, to minimize errors in reading and interpretations of letter forms that are deemed ambiguous or confusing (Direktorat Jendral Kependudukan dan Catatan Sipil Kementerian Dalam Negeri, 2017).

The reading of place names in The Epic of Hitu Land and Ancient Maps dated 1617, 1665, and 1753 resulted in several location names that have the same alphabetical arrangement and pronunciation. The names were then randomly arranged in a list of similar places. The list of place names allegedly mentioning the same location was then sorted horizontally from left to right (according to the chronology of The Epic of Hitu Land and the three ancient maps) and matched with the most recent village, sub-district and District/city location names in Ambon Island accessed from the Directorate General of Citizenship and Civil Registry of the Ministry of Home Affairs. The last column contains archaeological remains recorded in historical sources as well as those that can still be found today.

Based on the four historical sources, the researchers managed to identify 298 place names and 113 locations mentioned in more than 1 source. There are 35 locations from 113 locations that were successfully tracked on the most recent location data. In addition, there were also 6 place names that were only mentioned in one source, but their location can still be traced to this day. There are 41 place names in The Epic of Hitu Land and Ancient Maps dated 1617, 1665 and 1753 which locations can be found to date (see Table 1). For the record, the comparison of coordinates between the locations in the three ancient maps has a fairly good match and accuracy with the names of villages or countries or subdistricts on Ambon Island which includes the administrative areas of Ambon City and Central Maluku District.

Table 1. List of similarities in place names of the Epic of Hitu Land (period 1450-1646), ancient maps (1617, 1665, and 1753), and recent locations in new maps (2017)

\begin{tabular}{llllll}
\hline No & Hitu Epic & $\mathbf{1 6 1 7}$ map & $\mathbf{1 6 6 5}$ map & $\mathbf{1 7 5 3}$ map & New maps (2017) \\
\hline 1 & Mamala & Mamala & Mamalou & Mamala & $\begin{array}{l}\text { CM District, Leihitu Sub-district, Mamala } \\
\text { Village }\end{array}$ \\
\hline 2 & Wai & Way & Way & Way & $\begin{array}{l}\text { CM District, Salahutu Sub-district, Waai } \\
\text { Village }\end{array}$ \\
4 & - & Hattela & Hutela & Hatalae & $\begin{array}{l}\text { Ambon City, South Leitimur Sub-district, } \\
\text { Hatalai Village }\end{array}$ \\
4 & - & Soya & Soya & Soya & $\begin{array}{l}\text { Ambon City, Sirimau Sub-district, Soya } \\
\text { Village }\end{array}$ \\
6 & Larike & Laryke & Larique & Larike & $\begin{array}{l}\text { CM District, West Leihitu Sub-district, } \\
\text { Larike Village }\end{array}$ \\
7 & Hutumuri & Otemoery & - & Lilibay & $\begin{array}{l}\text { CM District, West Leihitu Sub-district, } \\
\text { Liliboy Village }\end{array}$ \\
8 & - & Lelybey & Lilleboy & Hoetoemoeri & $\begin{array}{l}\text { Ambon City, South Leitimur Sub-district, } \\
\text { Hutumury Village }\end{array}$ \\
9 & Kelang & Kylang & Kilan & Kilang & $\begin{array}{l}\text { Ambon City, South Leitimur Sub-district, } \\
\text { Hukurila Village } \\
\text { Ambon City, South Leitimur Sub-district, } \\
\text { Kilang Village }\end{array}$ \\
10 & Tiyal & Tiel & - & Thiel & $\begin{array}{l}\text { CM District, Salahutu Sub-district, Tial } \\
\text { Village }\end{array}$
\end{tabular}




\begin{tabular}{|c|c|c|c|c|c|}
\hline No & Hitu Epic & 1617 map & 1665 map & 1753 map & New maps (2017) \\
\hline 11 & - & Emma & Ema & Ema & $\begin{array}{l}\text { Ambon City, South Leitimur Sub-district, } \\
\text { Ema Village }\end{array}$ \\
\hline 12 & - & Nako & Nacou & Nako & $\begin{array}{l}\text { Ambon City, South Leitimur Sub-district, } \\
\text { Naku Village }\end{array}$ \\
\hline 13 & - & Roeton & - & Roeton & $\begin{array}{l}\text { Ambon City, South Leitimur Sub-district, } \\
\text { Rutong Village }\end{array}$ \\
\hline 14 & - & Bagual & - & $\begin{array}{l}\text { Veux Baguala; Pas } \\
\text { Baguala }\end{array}$ & Ambon City, Bagual Sub-district \\
\hline 15 & - & Hyto & - & Hitoe Lama & $\begin{array}{l}\text { CM District, Leihitu Sub-district, Hitulama } \\
\text { Village }\end{array}$ \\
\hline 16 & Lei Timol & - & - & - & Ambon City, South Leitimur Sub-district \\
\hline 17 & Alang & - & Alang & Alang & $\begin{array}{l}\text { CM District, West Leihitu Sub-district, } \\
\text { Allang Village }\end{array}$ \\
\hline 18 & Kicil & - & Hattos Kitjil & Ha .... Kithyl & $\begin{array}{l}\text { Ambon City, Sirimau Sub-district, Hative } \\
\text { Kecil Village }\end{array}$ \\
\hline 19 & & - & Tuileku & Tolehoe & $\begin{array}{l}\text { CM District, Salahutu Sub-district, Tulehu } \\
\text { Village }\end{array}$ \\
\hline 20 & - & - & Hounut & Hoenoet & $\begin{array}{l}\text { Ambon City, Teluk Ambon Sub-district, } \\
\text { Hunuth/Durian Patah Village }\end{array}$ \\
\hline 21 & - & - & Soulli & Soeli & $\begin{array}{l}\text { CM District, Salahutu Sub-district, Suli } \\
\text { Village }\end{array}$ \\
\hline 22 & - & - & Halou; Halau & $\begin{array}{l}\text { Halong; Vieux } \\
\text { Halong }\end{array}$ & $\begin{array}{l}\text { Ambon City, Baguala Sub-district, Halong } \\
\text { Village }\end{array}$ \\
\hline 23 & - & - & Wackal & Waccal & $\begin{array}{l}\text { CM District, Leihitu Sub-district, Wakal } \\
\text { Village }\end{array}$ \\
\hline 24 & - & - & Hatou & Hatoe & CM District, West Leihitu, Hatu Village \\
\hline 25 & $\begin{array}{l}\text { Nusatapi; } \\
\text { Hila }\end{array}$ & - & R. Den Hyla & Hila & $\begin{array}{l}\text { CM District, Leihitu Sub-district, Hila } \\
\text { Village }\end{array}$ \\
\hline 26 & Kaitetu & - & Caytetou & - & $\begin{array}{l}\text { CM District, Leihitu Sub-district, Kaitetu } \\
\text { Village }\end{array}$ \\
\hline 27 & Hatiwe & - & $\begin{array}{l}\text { Hativa } \\
\text { Weypie Hu }\end{array}$ & - & $\begin{array}{l}\text { Ambon City, Teluk Ambon Sub-district, } \\
\text { Hative Besar }\end{array}$ \\
\hline 28 & - & - & Batau Mera & - & $\begin{array}{l}\text { Ambon City, Sirimau Sub-district, Batu } \\
\text { Merah Village }\end{array}$ \\
\hline 29 & Nusaniwe & - & $\begin{array}{l}\text { Nafsamife } \\
\text { Lateuhalata; } \\
\text { Latuihalaha }\end{array}$ & - & $\begin{array}{l}\text { Ambon City, Nusaniwe Sub-district, } \\
\text { Latuhalat Village }\end{array}$ \\
\hline 30 & & - & Passo & - & $\begin{array}{l}\text { Ambon City, Baguala Sub-district, Passo } \\
\text { Village }\end{array}$ \\
\hline 31 & Wakasihu & Wackzuid & - & Waccafi (k/h?)oe & $\begin{array}{l}\text { *) same as no. } 14 \\
\text { CM District, West Leihitu Sub-district, } \\
\text { Wakasihu Village }\end{array}$ \\
\hline 32 & Asilulu & Affolodauri & - & Affaloeloe & $\begin{array}{l}\text { CM District, Leihitu Sub-district, Asilulu } \\
\text { Village }\end{array}$ \\
\hline 33 & - & - & - & Lateri & $\begin{array}{l}\text { Ambon City, Baguala Sub-district, Lateri } \\
\text { Village }\end{array}$ \\
\hline 34 & - & - & - & Tengahtengah & $\begin{array}{l}\text { CM District, Salahutu Sub-district, Tengah } \\
\text { Tengah Village }\end{array}$ \\
\hline 35 & & - & Lahari & Leahari & $\begin{array}{l}\text { Ambon City, South Leitimur Sub-district, } \\
\text { Leahari Village }\end{array}$ \\
\hline 36 & Uring & - & Ourien & Oerien & $\begin{array}{l}\text { CM District, Leihitu Sub-district, Ureng } \\
\text { Village }\end{array}$ \\
\hline 37 & - & - & - & Negri Lima & $\begin{array}{l}\text { CM District, Leihitu Sub-district, Negeri } \\
\text { Lima Village }\end{array}$ \\
\hline 38 & Kota Laha & - & - & Laha & $\begin{array}{l}\text { Ambon City, Teluk Ambon Sub-district, } \\
\text { Laha Village }\end{array}$ \\
\hline 39 & Seit & - & - & Ceyt & $\begin{array}{l}\text { CM District, Leihitu Sub-district, Seith } \\
\text { Village }\end{array}$ \\
\hline 40 & Kapahaha & - & Capaha & $\begin{array}{l}\text { Montagnes de } \\
\text { Capaha }\end{array}$ & $\begin{array}{l}\text { CM District, Leihitu Sub-district, Morela } \\
\text { Village }\end{array}$ \\
\hline 41 & Wawani & - & Wanany & Montagne Wawani & CM District, Leihitu, Kaitetu Village \\
\hline
\end{tabular}

Source: Direktorat Jendral Kependudukan dan Catatan Sipil Kementerian Dalam Negeri, 2017; Manusama, 1977; Anonim, 1617; Anonim, 1665; Anonim, 1753 
This study identified 12 villages with 22 archaeological remains. The referred villages are Soya, Hutumuri, Morela, Hitu Lama, Passo, Hila, Kaitetu, Seith, Negeri Lima, Ureng, Larike, and Laha (Figure 1). There are variations in the number of archaeological remains in the 12 villages which tend to be uneven, for example in Seith Village there is only one remains, which is Fort Seith, while in Hila Village the sites of the Lating Nustapi Old House, the Grand Mosque of Hila, the Old Church Imanuel of Hila, and Fort Amsterdam can be found. These cultural remains can be used to explain the historical context of the village as well as the village's origins.

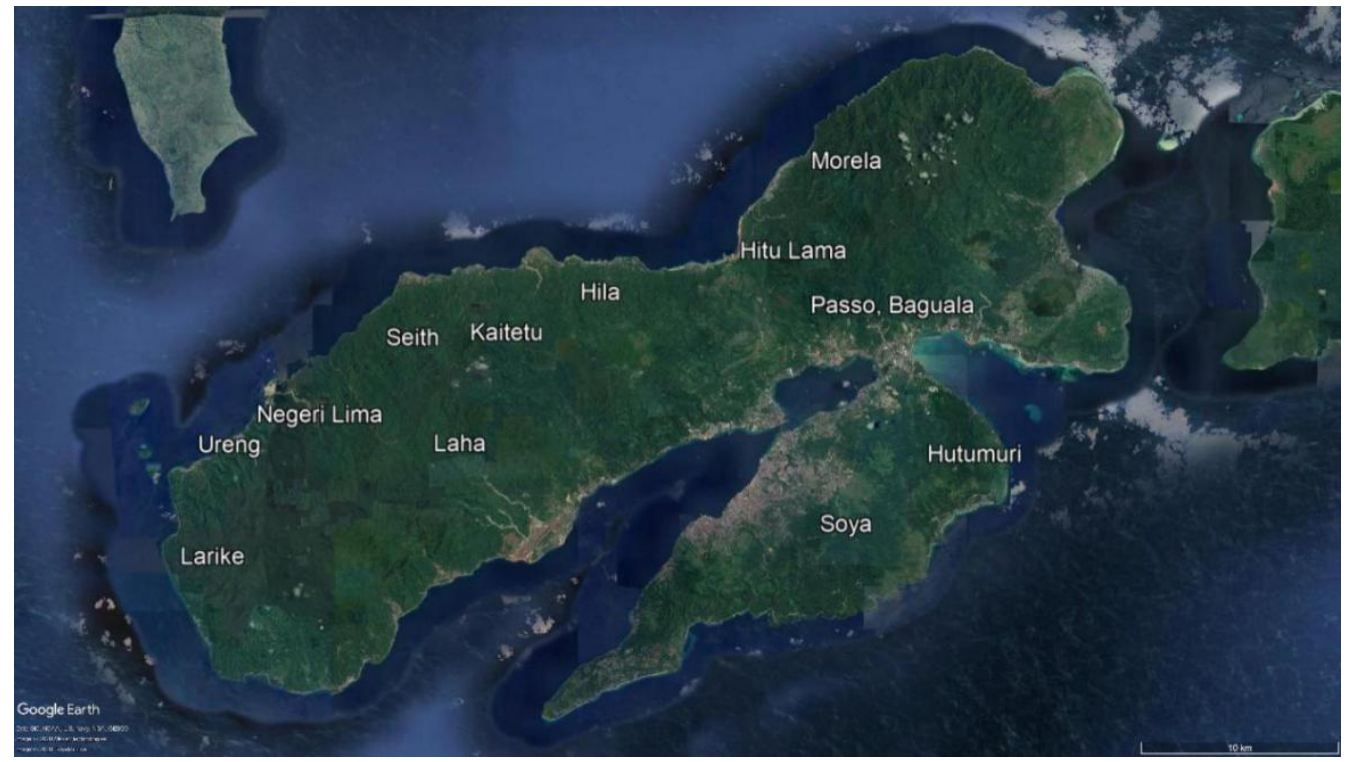

Figure 1. The distribution of 12 villages as the locus of this study (Source: Google Imagery, 2020)

\section{DISCUSSION}

\section{Soya Village}

Soya is not mentioned in The Epic of Hitu Land. However, the three ancient maps mention it as one of the lands (villages) in the Leitimor Peninsula. This is understandable because King (Village Chief) Soya, under the knowledge of the Dutch, received Portuguese refugees after the fall of Fort Portuguese. Abdurachman noted that there were 32 Portuguese families who fled to Soya (Abdurachman, 2008, p. 32). A part from Soya, descendants of Portuguese families are still living in the villages of Naku and Hatalai (Da Franca, 2000, p. 66). They then blended in with the local people and converted to Protestants (Protestant Christians).

The Soya people came from West Seram and gave their land the same name as the area they came from. They named it with the same name as a "memento" in memory of where they came from. According to John Rehatta (the Soya King), the meaning of the word Soya itself is "Truth in Words" (John Rehatta (King of Soya), pers. comm. 2 September 2020). The existence of the Soya King is at least strengthened by the legacy of the Old Soya House (Figure 2). This house was inhabited by the Kings of Soya for generations (Balai Pelestarian Cagar Budaya Maluku Utara, 2019).

In addition, in Soya Village, there is also the Old Church of Soya (Figure 3). This church is a pentagon-shaped building made of brick. The windows and doors have the same shape, made of wood and glass. Inside the church, there are 
special chairs for the Soya King and rows of seats for the congregation (Balai Pelestarian Cagar Budaya Maluku Utara, 2019).

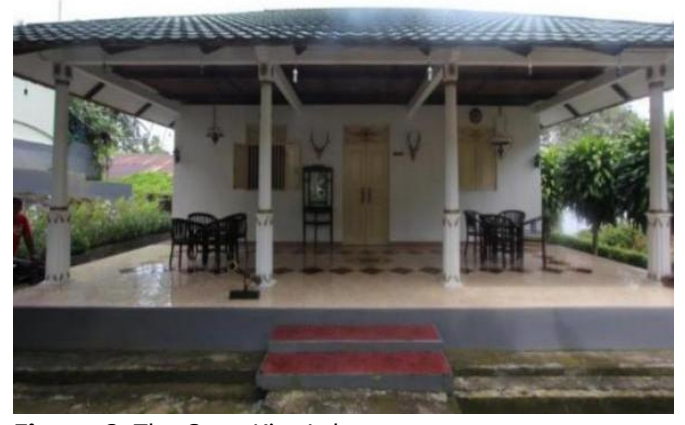

Figure 2. The Soya King's house.

(Source: Direktorat Pelindungan Kebudayaan, n.d.)

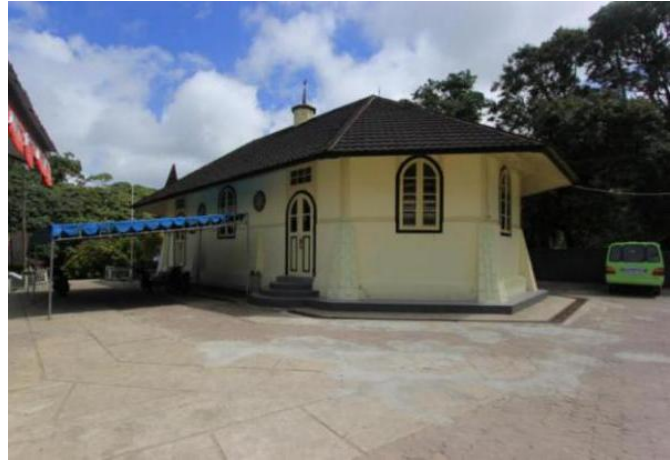

Figure 3. The church of Soya.

(Source: Balai Pelestarian Cagar Budaya Maluku Utara, $\underline{2019)}$

\section{Larike Village}

Larike's name is referred to in two ancient maps as "Laryke" (1617) and "Larique" (1665), unfortunately it remains unknown what Larike means. Larike Village was formed from the union of Hena Itu or Tujuh Negeri (the Seven Lands). The seven lands are Latadu, Wai Ata, Wai Lawo, Tipoke, Di u Polo, Asadu-Laha, and Wai Ta-o (Pattikayhatu, 2008, p. 100). According to the local story as conveyed by Pattikayhatu, the ancestors of the Larike people came from Java (Pattikayhatu, 2008, p. 101). Reportedly a Tuban named Raden Haji Mustafa was traveling for the purpose of spreading Islam. He then arrived at one of the Henas in Larike. He advised people to live on the beach, the settlement was later known as Riki. This name was later changed to Larike the meaning of it is unclear. Larike Village is now located in West Leihitu Sub-district, Central Maluku District. Apart from occupying a strategic geographical position on the west coast of Leihitu, Larike is also surrounded by tropical forests and clove plantations. This condition made Larike develop into the center of the VOC colony in Ambon Island.

According to Mansyur, Fort Rotterdam became the legacy of the Dutch which strengthened Larike's position as the center of trade and defense of the VOC in Ambon (Mansyur, 2012, pp. 6-7). In fact, Fort Rotterdam was founded by Governor Aert Gijsels in 1633. This fort was strengthened by 30 guards and a sergeant. Interestingly, De Vlaming Van Oudshoorn, one of the Governor Generals of the Dutch East Indies (1691-1704), was born in this fort in 1656. This fort almost fell in mid 1817. Luckily, Major Meyer and his troops were able to repel the rebels (Pusat Dokumentasi Arsitektur, n.d.). Today, Fort Rotterdam only has three sides of the fort wall and a piece of the surrounding wall (igure 4 and Figure 5). 


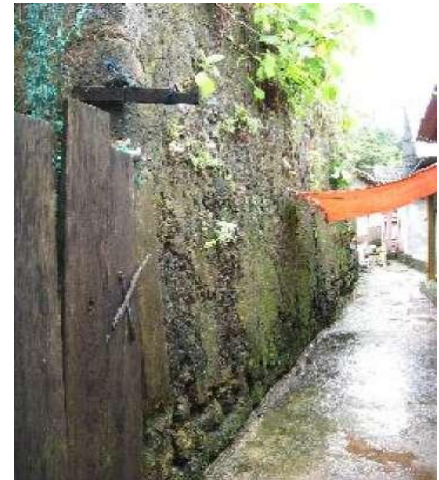

Figure 4. The remains of the walls of Fort Rotterdam.

(Source: Pusat Dokumentasi Arsitektur, n.d.)

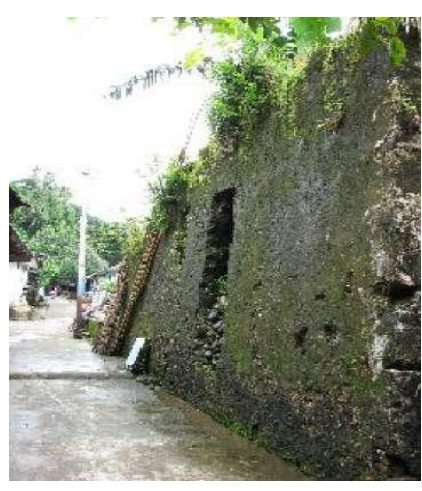

Figure 5. The remains of the walls of Fort Rotterdam.

(Source: Pusat Dokumentasi Arsitektur, n.d.)

\section{Hutumuri Village}

Hutumuri is mentioned once in an ancient map dating back to 1753 as Hoetoemoeri. The pronunciation is quite the same, only that it still uses the old spelling. Hutumuri is administratively the name of a village in the South Leitimur Sub-district, Ambon City. Hutumuri's geographic location is at the eastern end of the Leitimor Peninsula, thus making it directly adjacent to the high seas. This village is bordered by Leihitu Peninsula in the north, Rutong and Batu Merah Villages in the south, Halong Village in the west, and the Banda Sea in the east (Wattimena, 2009, p. 25).

The name Hutumury is etymologically composed of two words, namely Hotu and Muria. Hotu means to rise while Muria means behind. The people refer to Hutumury an episode of the war between the Portuguese and their allies (Soya) and the Lonusians. The Portuguese and their allies were unable to defeat the Lonusa people because they did not know the way to their settlement. Luckily the Portuguese were able to find the settlements of the Lonusa people and burn it down (Wattimena, 2009, pp. 24-25). While the Lonusa people were usually attacked from the interior, the Portuguese attacked from the coast instead. Therefore, the meaning of rise from behind can be understood as the Portuguese attack strategy on the Lonusa people. Later, they may refer to the area as Hutumury.

A different version was found by Joaquim Magalhaes de Castro when conducting an ethnographic study as well as conducting an interview with the traditional chief in the village. According to the traditional chief, the Dutch arrived in Lonusa after the Portuguese left the village because they faced strong defenses, then they finally set fire to them, so that all the residents fled (De Castro, 2019 , p. 162). That became the meaning of the name of the village today. Hutu means to descend and Muri means from the back door.

The two versions differ in the definition of "hutu" but have similarities in the definition of "muri". The word "hutu" generally means to go out. Both versions have the exact meaning according to the historical context of each version. If in the first version, the Portuguese went up into the mountains to destroy the Lonusa settlement, then in the second version the Lonusa people went down to save themselves from burning by the Dutch. It makes sense that the Dutch relics is presumably still left in Hutumury Village. Thus, Hutumuri contextually means "to go through a back lane or a different route".

If the material culture of Lonusa was likely to be burned by the Portuguese, then the material culture of the Portuguese was destroyed by the Dutch. The 
Dutch who occupied Ambon then built new buildings including the Protestant Church. The church that remains today is the Old Church of Hutumury (Figure 6). In addition, there are also three Dutch graves. One of the headstones has an inscription which explains that the burial was a Dutch person (Figure 7). The other two graves are not known because the inscription had faded (Direktorat Pelindungan Kebudayaan, n.d.).

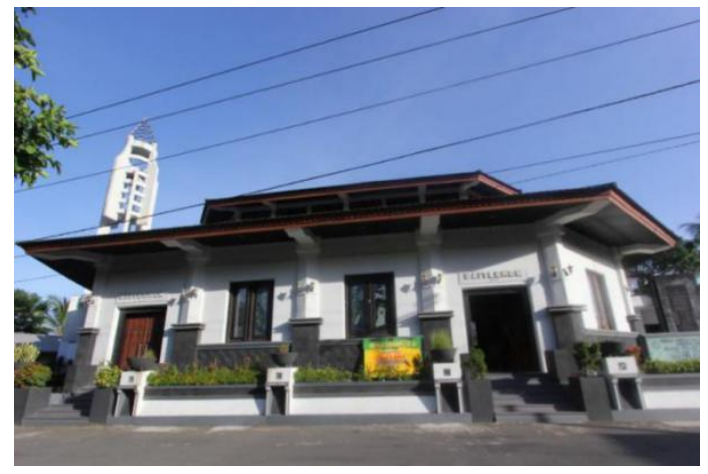

Figure 6. The front of the old church of Hutumuri. (Source: Direktorat Pelindungan Kebudayaan, n.d.)

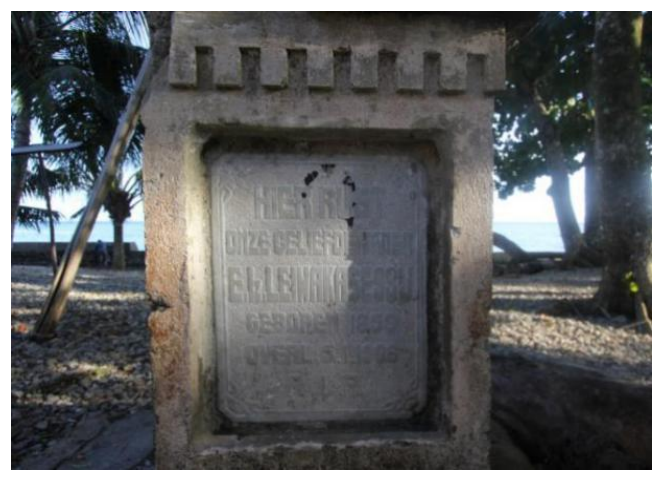

Figure 7. Inscription on one of the European tombs of Hutumuri.

(Source: Direktorat Pelindungan Kebudayaan, n.d.)

\section{Passo Village}

Passo is not mentioned in either The Epic of Hitu Land or the ancient map of 1665. Other sources only mention the name Bagual on the maps of 1617 (Bagual) and 1753 (Veux Baguala and Pas Baguala). Now, Passo is the name of a village under Baguala District. If Baguala was derived from the local language, which is "paukala" meaning "to connect" then Passo means "gate or way". According to Abdurachman and De Castro, the name Passo relates to the presence of the Portuguese in Ambon (Abdurachman, 2008, pp. 114-115; De Castro, 2019 , p. 144). After they were driven out of the Old Land (Hitu Lama), the Portuguese continued their evangelistic efforts by crossing the Hitu mountains until they arrived at Teluk Dalam between Negeri Rumah Tiga and Negeri Poka. They then settled in an area that seemed to be the meeting of the two peninsulas. Local people call the area Baguala. However, the Portuguese called it Passo because it was located at the meeting of the two peninsulas (Peninsulas Leihitu and Leitimor) on Ambon Island.

Neither the Passo Ambonese nor the Portuguese remains have been found there. Only the ruins of the Dutch Bongkah House remain (Figure 8 and Figure 9). The Dutch may have destroyed the material culture of the Portuguese and built on it new buildings. The house's name was derived from the capital of Zeeland province, Middelburg. The building was done in two stages, namely Middelburg I in the period 1626-1674, and Middelburg II in 1686. The shape of the boulder house is a square with a size of $10 \times 10 \mathrm{~m}$. There is a ladder to climb the room on the second floor which is on the west wall. The second floor was used for dwelling and has six windows. Blokhuis Midddelburg was occupied by 20 Dutch soldiers under the command of a sergeant and served as a place to collect taxes from the community on plantation products, trade and fishing products (Direktorat Pelindungan Kebudayaan, n.d.). 


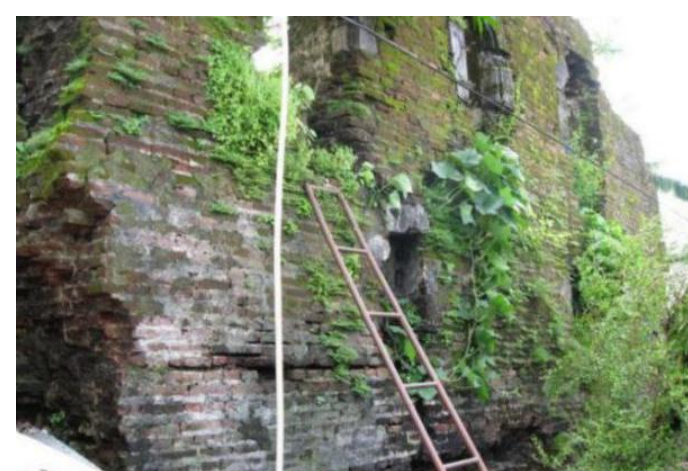

Figure 8. Outer walls of the Blokhuis Middelburg.. (Source: Direktorat Pelindungan Kebudayaan, n.d.)

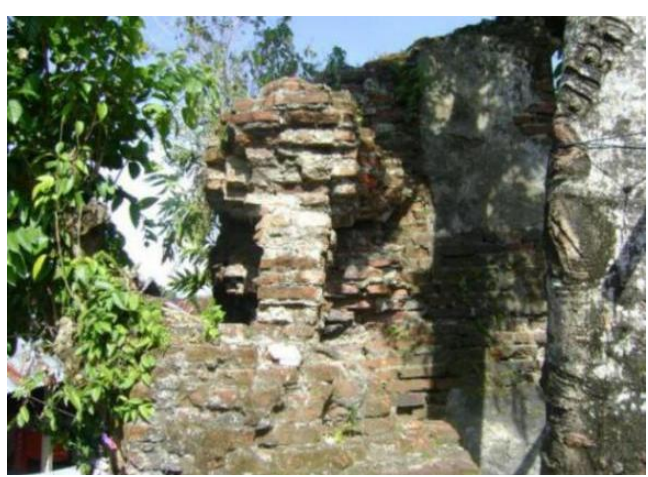

Figure 9. Blokhuis Middelburg side view. (Source: Direktorat Pelindungan Kebudayaan, n.d.)

\section{Hitulama Village}

Hitulama is mentioned in the ancient maps of 1617 (Hyto) and 1753 (Old Hitoe). Hitulama is the name of a village in the Leihitu Sub-district, Central Maluku District. Hitulama is known as one of the important locations or even the embryo of the existence of the Hitu Kingdom. Hitulama is located on the Leihitu Peninsula, on the northern coast of the northern mainland of Ambon Island. Geographically, most of Hitulama Village is in the mainland up to the hills, while the area covering the north coast is only about $5 \%$.

The name Hitulama consists of two words, namely Hitu and Lama. "Hitu" means seven and "lama" means early. Thus, Hitulama etymologically means "the seven who came earlier". Historically, at the initiation of four Perdanas (Perdana Totohatu, Perdana Tanahhitumessen, Perdana Nusatapi, and Perdana Pati Tuban), there were seven ulis (which oversees 30 lands) that agreed to establish an empire called the Sultanate of Hitu Land (Pattikayhatu, 2008, p. 159). However, the unity of the four Perdanas was split due to friction and colonial pressure so that Hitu was divided into three, namely Hitulama, Hila, and Hitumesing (Basman et al., 2012, p. 145; Manusama, 1977, p. 3).

The existence of Hitulama as the first foothold of the sultanate was strengthened by the existence of the legacy of the House of the Hitu Lama King in Hitulama Village (igure 10). In addition, there is a tomb complex for the Hitu kings in Hitulama Village. Wuri Handoko managed to identify several tomb complexes of the kings of Hitu (Handoko, 2014). Handoko found the tomb of King Maulana Syeh Abubakar Nasidik who is also known by the title Latusitania as the First Hitu King. This tomb is located on a plateau as high as an old mosque in Amahitu Village (Leihitu, Central Maluku District). The tomb of the Second Hitu King Maulana Ali Mahdun Ibrahim was also found (Handoko, 2014, p. 39). To the west of the tomb area of the Second Hitu King there is a stone structure believed to be the former foundation of the Tujuh Pangkat (Seven Levels) Mosque. In addition, he also found the Tomb of King Popoihu (the Fourth King of Hitu) which is located at an altitude of 39 masl and the Tomb of King Matiune (the Fifth Hitu King) located at an altitude of 33 masl.

Throughout the 16th century, the Hitu Sultanate did manage to survive the Portuguese penetration on the Leihitu Peninsula. However, the Portuguese expulsion served as the beginning and end of Hitu's own happiness. They collaborated with the Dutch who then established their dominance in the Leihitu Peninsula throughout the 17th century until the collapse of the Sultanate of Hitu Land. Wybrand van Waerwyck pioneered the Dutch arrivals by anchoring in Hitu Lama Bay in 1599. Much like the early arrivals of the Portuguese in Hitu, he 
was warmly welcomed by the local people. He wanted to build a fort. This fort was very useful not only as an initial position to attack the Portuguese and to counteract local rebellions (Pusat Dokumentasi Arsitektur, n.d.). The fort became known as Fort Leiden (Figure 11).

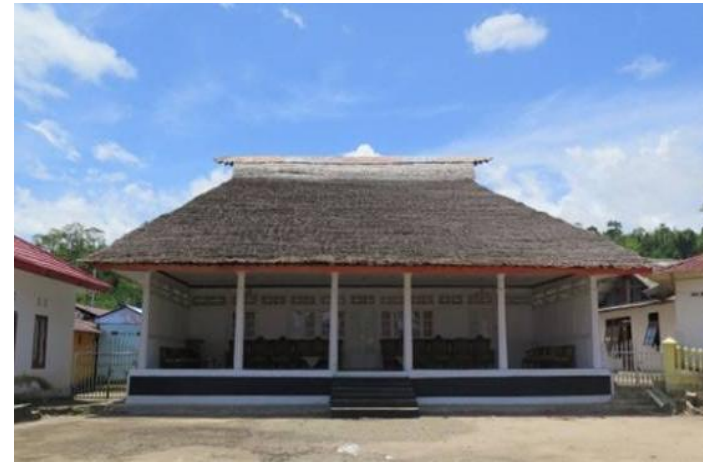

Figure 10. Home of the King of Hitu Lama Land. (Source: Direktorat Pelindungan Kebudayaan, n.d.)

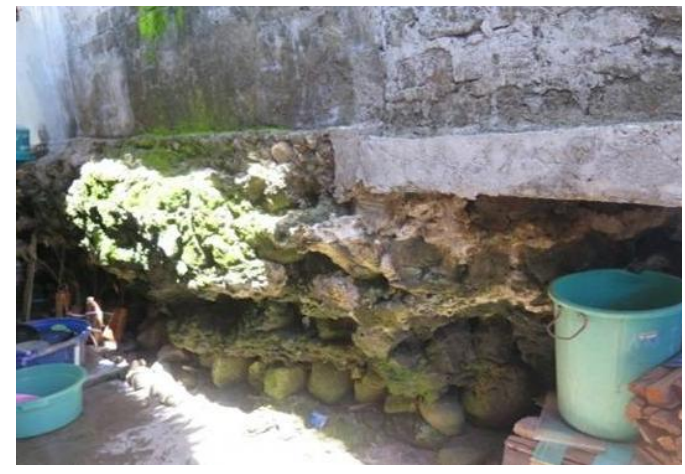

Figure 11. The remaining structure of Fort Leiden. (Source: Pusat Dokumentasi Arsitektur, n.d.)

\section{Hila Village}

The name Hila is mentioned several times by Rijali in The Epic of Hitu Land. In addition, the name Hila also appears on a map in 1665 as R. Den Hyla and a map in 1753 with the name Hila. Hila is a village in the Leihitu Sub-district, Central Maluku District. Hila has four soas namely Lating, Olong, Tatohatu, and Selang. The landscape of Hila Village is quite complex, consisting of hills on part of its main land. Part of it is a coastal area with a long coastline in the northern part of Ambon Island.

According to Manusama (Manusama, 1977, p. 3), Hila was a new area when Perdana Nustapi and his followers were forced to move together with their Aman and Soupele (Olong and Mosapal) westward from Hitu. Basman, et al, (Basman et al., 2012, pp. 39, 134) agree that Hila is also called "Hitu Baru". They then explained that Hila was occupied and overcrowded by the Hituese. This was intended to stem the influence of the Dutch in the Land of Hitu. Their explanation is considered quite odd, given the fact that the Portuguese first set foot in Ambon when they came to Hila. In fact, before the arrival of the Portuguese, Hila had developed into a trading center in the Leihitu Peninsula. Hila itself was built by Perdana Jamilu who came from Jailolo. Therefore, the word "hila" must be understood from the Jailolo language as well, that is "hira" meaning "behold over there" (Damri, caretaker of Fort Amsterdam, pers. comm. 3 September 2020).

The house of Perdana Jamilu (Perdana Nustapi or Hasan Sulaiman) is in Hila (Figure 12). Until now, the ownership of the king's house is still occupied by the descendants of Jamilu (Direktorat Pelindungan Kebudayaan, n.d.). Apart from the old house, in Hila there is still a mosque (Figure 13) which was founded in the 17th century (Direktorat Pelindungan Kebudayaan, n.d.). As a result of the alliance between Hitu and the Dutch to expel the Portuguese from Ambon, the Dutch were given space to build their forts. The Dutch then built a fort and named it Fort Amsterdam (Balai Pelestarian Cagar Budaya Maluku Utara, 2014). Apart from Fort Amsterdam (Figure 14), the Dutch also built a church, known as the Old Church Imanuel of Hila (Figure 15). 


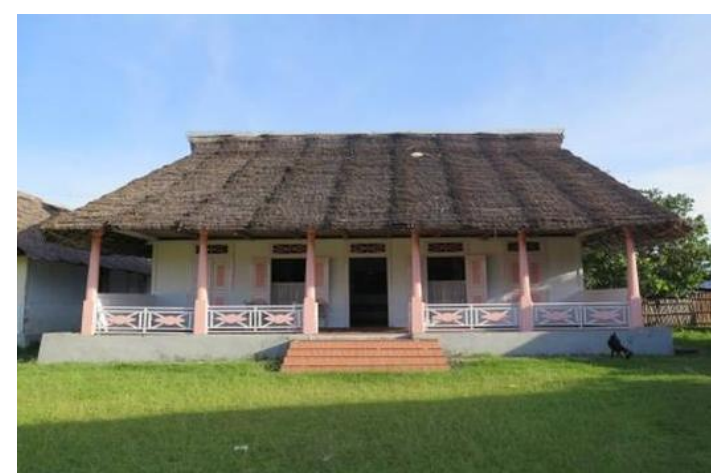

Figure 12. The Old Hila House. (Source: Direktorat Pelindungan Kebudayaan, n.d.)

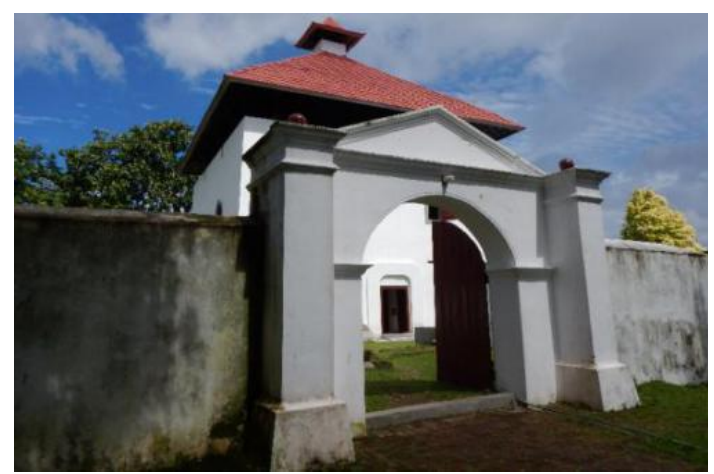

Figure 14. Amsterdam Fort entrance. (Source: Balai Pelestarian Cagar Budaya Maluku Utara, 2014)

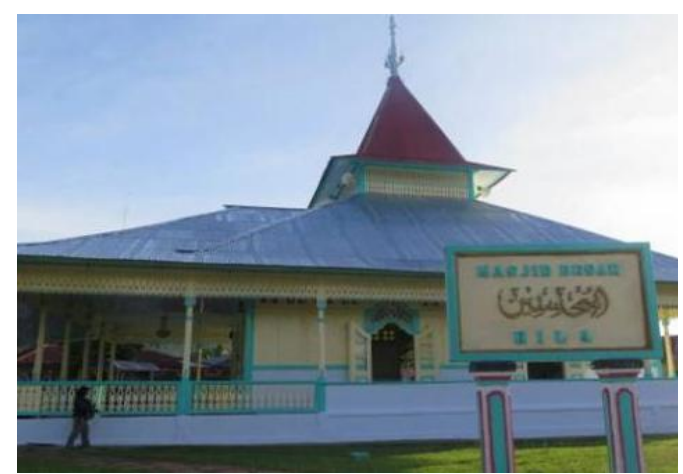

Figure 13. The Grand Mosque of Hila. (Source: Direktorat Pelindungan Kebudayaan, n.d.)

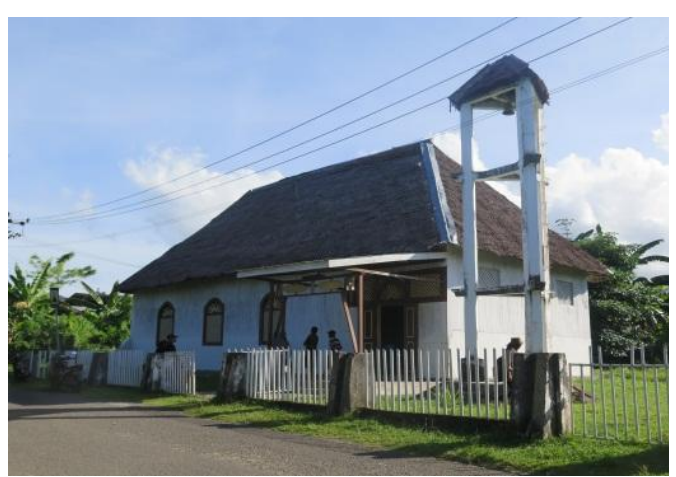

Figure 15. The Old Church Imanuel of Hila. (Source: Direktorat Pelindungan Kebudayaan, n.d.)

\section{Kaitetu Village}

Kaitetu or Caytetou only appears once on a map in 1665. Kaitetu is the name of a village in the Leihitu Sub-district, Central Maluku District. Kaitetu Village has five henas or amans, namely Esen, Wawane, Atetu, Nokohali, and Tehala (Pattikayhatu, 2008, p. 140). Kaitetu's geographic condition is very similar to Hila, which consists of hills on the south side and coast in the north. The hills in Kaitetu can be said to be relatively higher than Hila. This similar environmental condition is due to the location of the two adjacent villages. Kaitetu is located just west of Hila.

Kaitetu comes from two words, namely "kai" and "tetu". "Kai" means paddle and "tetu" means headland. Etymologically, kaitetu means "to row until the headlands". The name Kaitetu relates to the forced migration that the Dutch imposed on the local people on Mount Wawane (Ala Hahulu) in the 17th century. They were moved from the mountains to the place where they now live. They used water transportation to move because land roads were difficult for people to pass (Keuning, 2016, p. 2). Water transportation with various types and sizes of ships has been widely used. Therefore, the people who rowed their ships to reach the territory determined by the Dutch came to be known as Kaitetu. This urbanization was carried out by the Dutch so that they could stay and be close to the first Dutch fort that was established, which is Casteel van Verre (Basman et al., 2012, p. 120).

In Kaitetu, there is an Islamic heritage, namely the Old Mosque of Wapauwe (Figure 16). This mosque has an area of $100 \mathrm{~m} 2$ and a veranda of $30.16 \mathrm{~m} 2$. Initially, this mosque did not have a veranda. However, this mosque is unique in that it does not use nails in any wooden joints in the construction of the building. In addition, there are Allah and Muhammad written in every corner on the roof 
of the mosque (Direktorat Pelindungan Kebudayaan, n.d.). When the Dutch domination became rampant in Kaitetu, the Kaitetu people did not comply with all Dutch instructions. They resisted and hid on Mount Wawane (Figure 17). Under Kakiali, they carried out guerrillas from the stronghold they had built (De Graaf, 1977, pp. 81-82). Although there were no remains of the fort structure, two cannons, a stone table, fragments of ceramic and pottery were found inside the stronghold (Balai Pelestarian Cagar Budaya Maluku Utara, 2011).

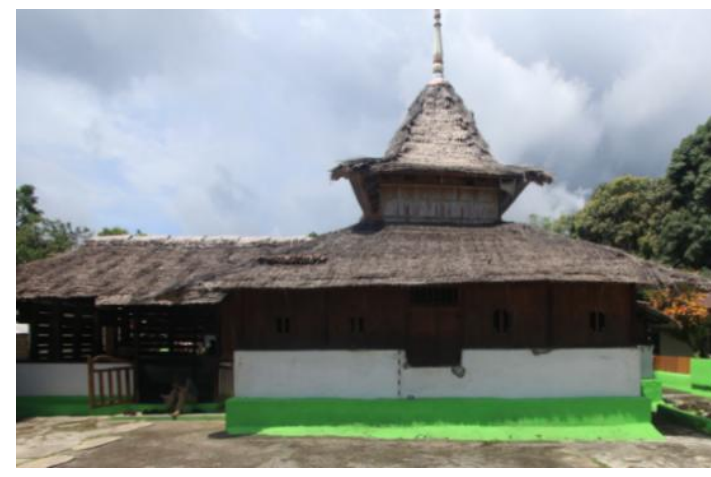

Figure 16. The Old Mosque of Wapauwe. (Source: Direktorat Pelindungan Kebudayaan, n.d.)

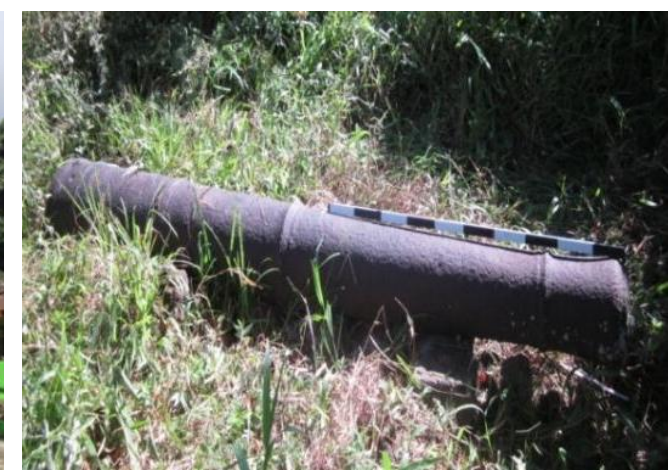

Figure 17. Cannon relics on Mount Wawane. (Source: Balai Pelestarian Cagar Budaya Maluku Utara, 2011)

\section{Ureng Village}

Ureng is mentioned on maps of 1665 and 1753 by the names Ourien and Oerien. The arrangement of letters used can be said to be very different. The pronunciation is almost the same, except that it does not end with "ng" or buzzing. However, based on the identification of the two maps, the location of Ourien and Oerien matches the coordinate point of Ureng Village, which is in Leihitu Sun-district, Central Maluku District. The village of Ureng consists of seven hamlets, namely Oerien-bessy, Bessi-mantula, Luhelu, Lelialin, Sobaitu, Lecatulin, and Alipatan. Ureng is located in the southwestern part of the Leihitu peninsula, with hilly landscapes to the south and coast to the north.

Ureng or Uring is one of the nine henas in Uli Siwa, which is located west of Uli Hitu. Hena Uring is led by Upu Hena (Manusama, 1977, p. 2). Although Pattikayhatu (Pattikayhatu, 2008, p. 116) reveals that the meaning of the word Ureng is unclear, the oral tradition in Uring Village, as rewritten by Basman, et al. (Basman et al., 2012, p. 33), mentions the phrase "Uli Yala Yopa Hitu Hua Barkate". It could be that the name Ureng, in accordance with that expression, means "to submit oneself" to uli Hitu. After the Portuguese were successfully expelled, the Dutch were given a place alongside Hitu to run Ambon. Unfortunately, the Dutch influence was getting stronger and Hitu fell into their control. The influence of the Dutch can be proven by the existence of a fort called Fort Uring (Figure 18). 


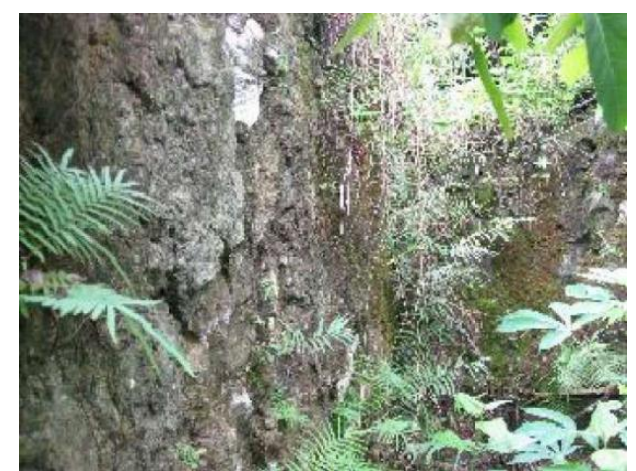

Figure 18. The remains of the walls of Fort Ureng. (Source: Pusat Dokumentasi Arsitektur, n.d.)

\section{Negeri Lima}

Negeri Lima is mentioned on the 1753 map as Negri Lima. Negeri Lima is a village in the Leihitu Sub-district, Central Maluku District. Negeri Lima is located next to Ureng, to the northeast of Ureng to be precise. Their landscapes are the same, with steep hills to the south and coast to the north.

In simple terms, the name "Lima" means "a combination of five hamlets". The five villages are Nau, Binau, Henalatua, Henalale, and Henahelu. They named the union of the five hamlets Uli Nau Binau (Pattikayhatu, 2008, p. 120). As a result of the Dutch occupation of Tanah Hitu, the five hamlets descended to the coast and built a village together which they named Negeri Lima (Basman et al., 2012, pp. 140-141). Negeri Lima was a Dutch colony as evidenced by the remaining Dutch cultural heritage, namely Fort Van Harlem (igure 19).

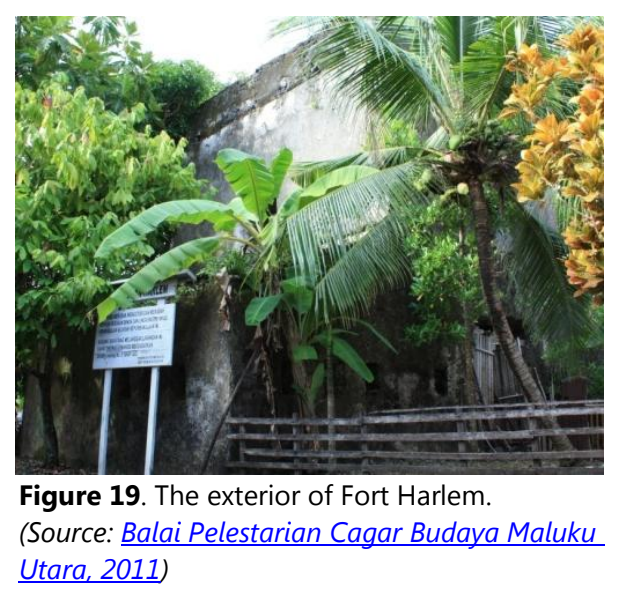

\section{Laha Village}

Laha, was mentioned once in the 1753 map with the same name. Laha is the name of a village in the Teluk Ambon Sub-district, Ambon City. The origin of Laha Village cannot be separated from the presence of the Portuguese. After they were driven out of the Leihitu Peninsula, they began to build Fort Nossa Senhora de Anunciada in 1575. The local people later called it the City of Laha or the City "in the bay" (De Graaf, 1977, pp. 125-126). The fort is now destroyed and only traces of burnt stones remain (Figure 20). After the city of Laha fell into the Dutch hands, the Dutch immediately changed its name. The fortress was named Fort Victoria (Figure 21). Fort Victoria is now located in Honipopu Village, west of Mardika Market, in Ambon City (Direktorat Pelindungan Kebudayaan, n.d.). 


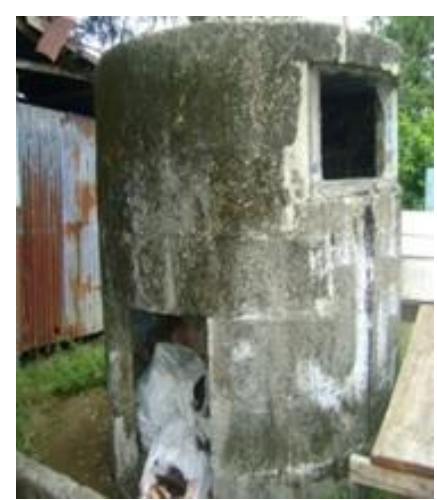

Figure 20. The remains of Fort Portuguese.

(Source: Direktorat Pelindungan Kebudayaan, n.d.)

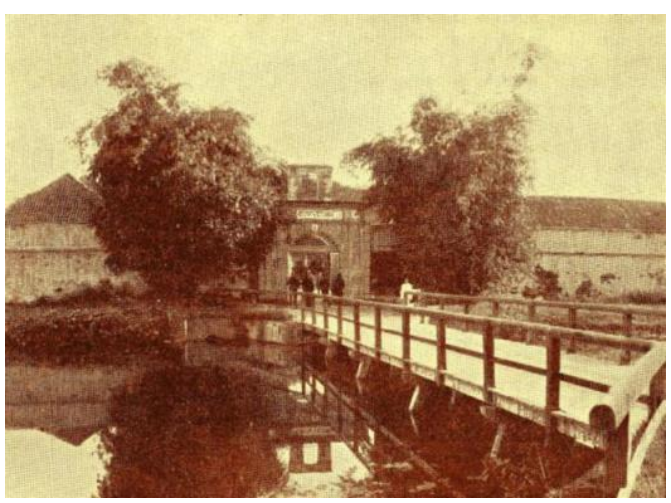

Figure 21. Fort Victoria taken in 1890.

(Source: Direktorat Pelindungan Kebudayaan, n.d.)

\section{Seith Village}

Seith appears on the 1753 map as Ceyt. Seith is a village in the area of Leihitu Sub-district, Central Maluku District. Seith Village is a combination of five soas, namely Seith, Hautuna, Lehu-Lehu, Wasila, and Laijn. The origin of Seith village is still not known for certain. However, the remaining cultural relic is Seith Fort (Figure 22 and Figure 23). This fort was originally founded by the Hituese who were assisted by troops from Makassar. The Dutch then took over the fort and made it the center of VOC operations in 1643. They then rebuilt the fort with stones. The Fort and the Village of Seith were devastated when a severe earthquake hit in mid-1674. In the period after 1697, the Dutch then concentrated on Ambon City as the center of their activities and withdrew their troops outside Ambon. The shape and plan of the fort cannot be described anymore. This is because of the condition of the fort that is already destroyed. Currently, only the remains of the foundation and some fortress materials can be found in the yards of the residents' houses (Pusat Dokumentasi Arsitektur, n.d.).

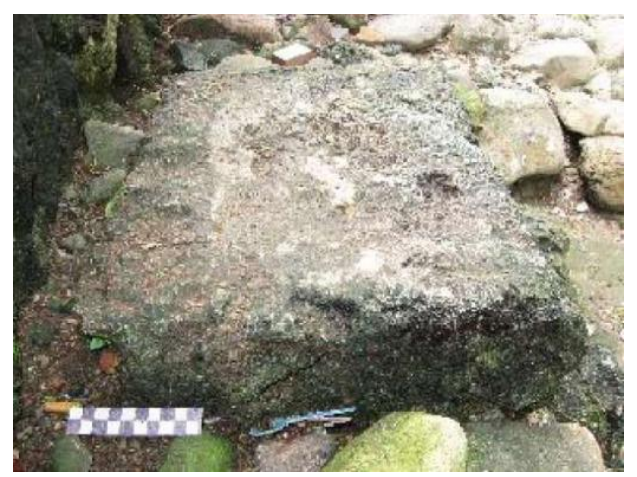

Figure 22. The remains of Fort Seith foundation. (Source: Pusat Dokumentasi Arsitektur, n.d.)

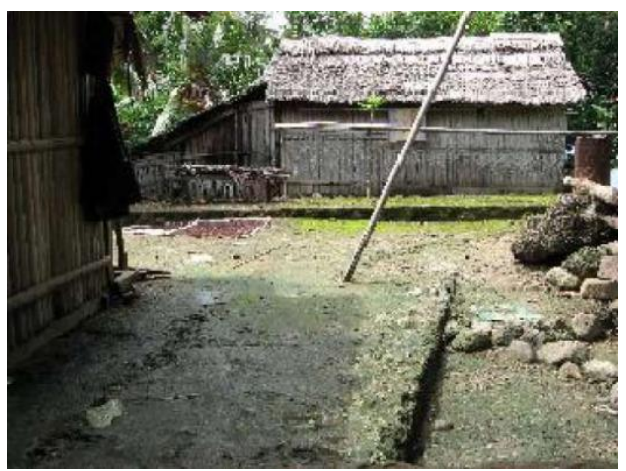

Figure 23. The environment around Fort Seith. (Source: Pusat Dokumentasi Arsitektur, n.d.)

\section{Morela Village}

Two ancient maps of 1665 and 1753 do not mention Morela's name. Both mention Capaha and Montagnes de Capaha. Capaha is not the name of a village, but the name of a fortress, which is Fort Kapahaha (Figure 24). This fort belonged to the legendary Kapitan Hitu named Telukabessy, the defense hero of Hitu (De Castro, 2019, p. 152). This fort was a silent witness to the struggle of the people of Hitu Land against the Dutch army. In that battle, many warriors of the Land of Hitu were killed. The battle took place in 1646 (Basman et al., 2012, p. 140).

Fort Kapahaha is located on a natural hilly area that forms the walls of the 
fort. The walls of the fort are naturally formed rocks or karst. It is unmistaken that Kapahaha, which can be interpreted as "steep hill" (Pattikayhatu, 2008, p. 181) is located in Morela Village, Leihitu Sub-district, Central Maluku District. This identification was obtained through a comparison of the location of Capaha which currently shows to be in Morela Village, precisely in the area where Fort Kapahaha is located.

Pattikayhatu (Pattikayhatu, 2008, p. 182) explains the meaning of the word Morela. Morela comes from the word "Muar Ela (the Great King)" or "Umar Ela (the Great Umar)". Based on the folklore of the Indigenous Elders in Morela, Morela Village was built by Ama Ela. He then had six children whose descendants were bound together in three soas and founded Morela Village. The three soas are Ela Halu, Hatu Mena, and Hena Huku.

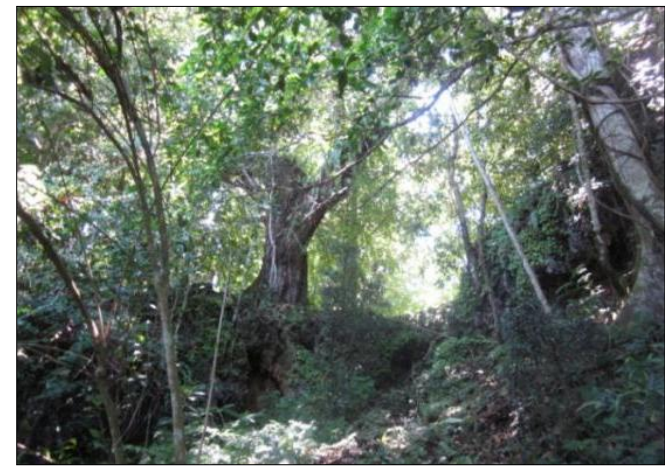

Figure 24. Kapahaha defense stronghold.

(Source: Balai Pelestarian Cagar Budaya Maluku Utara, 2011)

\section{CONCLUSION}

Various historical events have given color to the development of villages on Ambon Island. The multicultural legacy formed from the global meeting is the evidence of cultural crossovers on Ambon Island. Toponymy studies are not only about examining the origins of place names but also uncovering the cultural crossings in Nusa Ambon. The origins of Soya Village in the Leitimor Peninsula can be comprehended through an historical and archaeological approach. The residents named their residence as a remembrance of their home village on Seram Island. In addition, archaeological remains can also be used to explain the role of contemporary culture. Hila Village literally means "behold over there". The meaning "behold over there" refers to the coast of Hila where Hila is the center of trade in the Leihitu Peninsula. In later times, many people settled and developed their culture through high economic activity.

Various archaeological remains can be used to explain their existence. If the Mosque of Hila represents the presence of the Ambon-Hituese in Hila, then the Old Church of Hila is a characteristic of a Christian city built by the Dutch. This study can serve as an applicable model for archaeologists and historians. Apart from being able to obtain a complete picture regarding the origin of certain place names, the historical and archeological approach can open up a wealth of data sources, both historical and archaeological data. This research can be a model for archaeologists in the study of cultural heritage with historical contexts. Meanwhile, for historians, this research can enrich the treasures of Ambonese historiography, particularly Ambonese cultural history. 


\section{RECOMMENDATION}

The limited scope of research during the pandemic has caused data collection to be carried out uncomprehensively. This research was only able find 12 names of villages with 22 archaeological remains. If Ambon is one of the protectors of the oral tradition, then the meaning of the village names that have not yet been identified (Larike and Seith Village) can be further explored.

\section{AUTHOR DECLARATION}

All Authors contributed to the creation of this manuscript. Daya Negri Wijaya, Deny Yudo Wahyudi, and Siti Zainatul Umaroh served as primary contributors, while Ninie Susanti and Rendy Aditya P.E. served as secondary contributors. The manuscript has been read and approved by all authors. The order of authors listed in the manuscript has been approved by all named authors. All authors did not receive funding for the creation of this manuscript. All authors confirm that there are no known conflicts of interest associated with this publication and there has been no significant financial support for this work that could have influenced its outcome. All authors adhered to the Copyright Notice set by Berkala Arkeologi.

\section{ACKNOWLEDGEMENT}

The authors would like to thank the Directorate of Culture Development and Utilization, Ministry of Education and Culture for facilitating the project "Penulisan Buku Zamrud Khatulistiwa: Kota-Kota di Jalur Rempah pada Era Kejayaan Nusantara Tahun 2020" (The 2020 Writing the Book of the Equatorial Emerald: Cities on the Spice Route in the Archipelago's Glorious Era ). With this facilitation, the writing of this article can be done. In addition, the authors also express their gratitude for various valuable inputs from the editors and proficient partners of this journal. 


\section{REFERENCES}

Abdurachman, P. (2008). Bunga angin Portugis di Nusantara: kejak-jejak kebudayaan Portugis di Indonesia. LIPI Press.

Balai Pelestarian Cagar Budaya Maluku Utara. (2011). Laporan inventarisasi cagar budaya kabupaten Maluku Tengah dan kota Ambon.

Balai Pelestarian Cagar Budaya Maluku Utara. (2014). Laporan zonasi balai pelestarian cagar budaya Maluku Utara.

Balai Pelestarian Cagar Budaya Maluku Utara. (2019). Laporan kegiatan kajian pelestarian kawasan cagar budaya negeri Soya kota Ambon.

Basman, A., Toisuta, H., Rajab, H., Wakano, A., \& Baharudin, A. (2012). Sejarah sosial kerajaan Hitu Ambon. Kementerian Agama.

Da Franca, A. P. (2000). Pengaruh Portugis di Indonesia. Sinar Harapan.

De Castro, J. M. (2019). Lautan rempah peninggalan Portugis di Nusantara. Kompas Gramedia.

De Graaf, H. J. (1977). De geschiedenis van Ambon en de zuid Molukken. Uitgeveritj T. Wever.

Deliani, S. (2016). Toponimi kota Medan (dalam relativitas linguistik). Seminar Nasional Toponimi: Toponimi Dalam Perspektif Ilmu Budaya, 266-270. https://linguistik.fib.ui.ac.id/seminar-toponimi/

Direktorat Jendral Kependudukan dan Catatan Sipil Kementerian Dalam Negeri. (2017). Data kependudukan provinsi Maluku per semester 1 bulan juni tahun 2017.

Direktorat Pelindungan Kebudayaan. (n.d.). Sistem registrasi cagar budaya nasional. http://cagarbudaya.kemdikbud.go.id/

Handoko, W. (2014). Tradisi nisan menhir pada makam kuno raja-raja di wilayah kerajaan Hitu. Kapata Arkeologi, 10(1), 33-46. https:// doi.org/10.24832/kapata.v10i1.216

Keuning, J. (2016). Sejarah Ambon sampai akhir abad ke-17. Ombak.

Leirissa, R. ., Ohorella, G. A., \& Latuconsina, D. (1999). Sejarah kebudayaan Maluku. Departemen Pendidikan dan Kebudayaan.

Leirissa, R. ., Pattikayhatu, J. A., Luhukay, H., Talib, U., \& Maelissa, S. (2004). Ambonku dulu, kini, dan esok. Pemerintah Kota Ambon.

Mansyur, S. (2012). Peran wilayah negeri Larike pada masa kolonial. Kapata Arkeologi, 8(2), 65-72. https:// doi.org/10.24832/kapata.v8i2.188

Manuhutu, F. S. (2002). Toponimi di kota Ambon: laporan penelitian.

Manusama, Z. J. (1977). Hikayat tanah Hitu: historie en sociale van de Ambonse Elanden in het algemeen en van Uli Hitu in het bijzonder tot het midden der zeventiende eeuw. Rijksuniversiteit te Leiden.

Munandar, A. A. (2016). Toponimi dalam kajian arkeologi. Seminar Nasional Toponimi: Toponimi Dalam Perspektif Ilmu Budaya, 1-26. https://linguistik.fib.ui.ac.id/seminar-toponimi/

Pattikayhatu, J. A. (2008). Sekilas kota Ambon dan provinsi Maluku. Citra Aji Parama.

Pusat Dokumentasi Arsitektur. (n.d.). Benteng Indonesia. http:// benteng.architectureheritage.or.id

Rais, J., Lauder, M., Sudjiman, P., Ayatrohaedi, Sulistyo, B., Wiryaningsih, A., Suparwati, T., \& Santoso, W. E. (2008). Toponimi Indonesia: sejarah budaya yang panjang dari permukiman manusia $\mathcal{E}$ tertib administrasi. Pradnya Paramita.

Suratminto, L. (2016). Nama-nama tempat di Jakarta dan kaitannya dengan masa 
kolonial. 37-54. https://linguistik.fib.ui.ac.id/seminar-toponimi/

Wattimena, L. (2009). Rumah adat Baileo: interpretasi budaya di negeri Hutumuri kecamatan Leitimur Selatan kota Ambon. Kapata Arkeologi, 5(8), 23-34. https:// doi.org/10.24832/kapata.v5i8.107

Widyastuti, M. (2016). Penyebutan makam di dalam masyarakat Jawa. Seminar Nasional Toponimi: Toponimi Dalam Perspektif Ilmu Budaya, 196-207. https://linguistik.fib.ui.ac.id/seminar-toponimi/ 